\title{
Imaging the tectonic framework of the 24 August 2016, Amatrice (central Italy) earthquake sequence: new roles for old players?
}

\author{
LORENZO BONINI ${ }^{* 1}, 2$, FRANCESCO EMANUELE MAESANO2, ROBERTO BASILI ${ }^{2}$, \\ PiERFRANCESCO BURRATO2, MiCHELE MATTEO COSIMO CARAFA ${ }^{3}$, UMBERTO \\ FRACASSI ${ }^{2}$, VANJA KASTELIC ${ }^{3}$, GABRIELE TARABUSI ${ }^{4}$, MARA MONICA TIBERTI ${ }^{2}$, \\ PAOLA VANNOLI ${ }^{2}$, GIANLUCA VALENSISE ${ }^{2}$
}

\begin{abstract}
${ }^{1}$ Dipartimento di Matematica e Geoscienze, Università di Trieste, Italy 2Istituto Nazionale di Geofisica e Vulcanologia, Sezione Roma 1, Roma, Italy 3Istituto Nazionale di Geofisica e Vulcanologia, Sezione Roma 1, L'Aquila, Italy ${ }^{4}$ Istituto Nazionale di Geofisica e Vulcanologia, Sezione Roma 1, Bologna, Italy
\end{abstract}

*lbonini@units.it

\begin{abstract}
We reconstruct the tectonic framework of the 24 August 2016, Amatrice earthquake. At least three main faults, including an older thrust fault (Sibillini Thrust), played an active role in the sequence. The mainshock nucleated and propagated along an extensional fault located in the footwall of the Sibillini Thrust, but due to the preliminary nature of the data the role of this thrust is still unclear. We illustrate two competing solutions: 1) the coseismic rupture started along an extensional fault and then partially used the thrust plane in extensional motion; 2) the thrust fault acted as an upper barrier to the propagation of the mainshock rupture, but was partially reactivated during the aftershock sequence. In both cases our tectonic reconstruction suggests an active role of the thrust fault, providing yet another example of how structures inherited from older tectonic phases may control the mainshock ruptures and the long-term evolution of younger seismogenic faults.
\end{abstract}

\section{INTRODUCTION}

$\mathrm{T}$ he $\mathrm{M}_{\mathrm{w}}$ 6.0, 24 August 2016, Amatrice earthquake devastated a mountainous area of the Central Apennine, claiming nearly 300 casualties. Its aftershock sequence spreads over a NNW-SSE trending, 30-km-long, 15-kmwide area (Fig. 1). Interferometric Synthetic Aperture Radar (InSAR) elaborations based on various sensors and processing strategies depict a gently asymmetric coseismic ground dis- 
placement pattern having two subsidence maxima of 15-20 cm east of Norcia and north of Amatrice (Fig. 1b). The first post-earthquake field surveys revealed an alignment of surface breaks (fissures, open fractures and centimetric offsets), in an area including the western flank of Mt. Vettore (Fig. 1b; Emergeo Working Group, 2016); ground failures of various types were also observed over a much larger area (CERI Working Group, 2016).
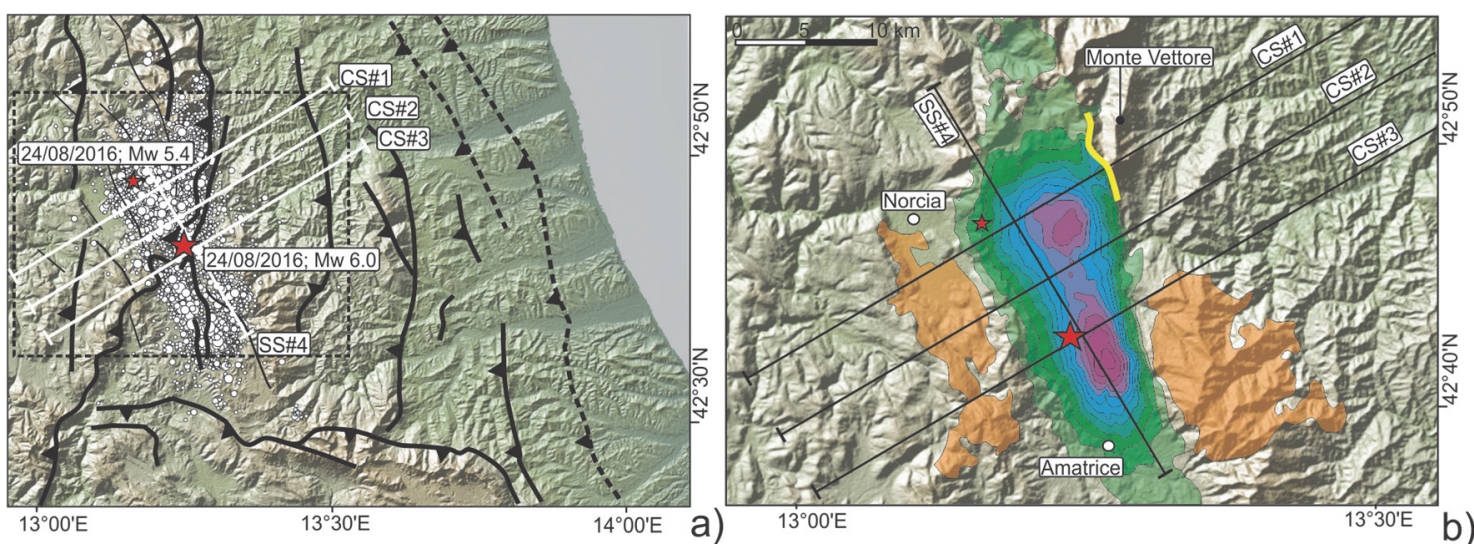

Figure 1. a) Simplified tectonic map of the area struck by the 24 August 2016, Amatrice earthquake sequence (updated as of 15 September 2016). Red stars indicate the largest earthquakes: the mainshock (Mw 6.0), and the largest aftershock (Mw 5.4). White dots represent the aftershock epicenters. White lines indicate the trace of the cross-sections used to image the sequence and the geological structures at depth. b) Line drawing of the subsidence isolines shown by the ALOS-2 interferogram (LOS point of view; available from http://www.eorc.jaxa.jp/ALOS-2/en/img_up/dis_pal2_ita-eq_20160825.htm), describing the surface deformation detected after the mainshock (orange areas: uplift; green-purple areas: subsidence).

The moment tensor solutions of the mainshock and of the largest aftershocks (http://cnt.rm.ingv.it/tdmt) indicate the activation of extensional faults striking NNW-SSE and dipping $40^{\circ}-50^{\circ}$. Ongoing extension in the area is testified by the analysis of crustal strain and seismicity data (e.g. Carafa and Bird, 2016), yet the tectonic setting and the landscape of the region are still dominated by the contractional structures of the Neogene-Quaternary Apennines fold-and-thrust belt. The extension in the Apennines is indeed a relatively youthful process (e.g. Maliverno and Ryan, 1986) that proceeds at the relatively slow rate of $2-3 \mathrm{~mm} / \mathrm{yr}$ (Carafa and Bird, 2016). Consequently, the currently active structures have not yet fully reshaped the Apennines highs-and-lows of contractional origin with extensional basin-and- range-type landforms. It is worth recalling that some of the well-exposed extensional faults, generally bounding an intermountain basin, were created by a pre-orogenic (Mesozoic) or by a syn-orogenic extensional (Miocene) regime and were shifted to their present location during the Neogene thrusting phase, for instance through a shortcut mechanism (positive inversion tectonics; e.g. Tavarnelli, 1996; Butler et al., 2006; Scisciani, 2009).

The complex framework described above explains why identifying and characterizing seismogenic sources in the Apennines is extremely challenging (see Vannoli et al., 2012, and Bonini et al., 2014, for a discussion on this topic). However, the detailed information that exists on Italy's geology (e.g. geological maps, seismic re- 
flection data and deep well logs from hydrocarbon exploration) can be combined with postearthquake high-resolution seismological and geodetic data to propose coherent seismotectonic models.

This study provides a preliminary interpretation of the sources of the Amatrice earthquake sequence through the integration of all available geological, seismological, and geodetic data. We propose a scheme of the fault systems that participated in the earthquake sequence. We then discuss the implications that our findings may have on future research about the seismotectonic characterization of the Apennines.

\section{SEISMOTECTONIC MODELING}

The Amatrice earthquake sequence struck an area straddling the southern and curved part of one of the main regional thrusts of the Central Apennines: the Sibillini Thrust system (e.g. Cantalamessa et al., 1982; Bally et al., 1986; Ghisetti and Vezzani, 1991; Calamita et al., 2003; Bigi et al., 2011). This large thrust separates two markedly different geological domains: the Meso-Cenozoic "Umbria-Marche" carbonate succession, to the north, and the "Laga Basin" succession, formed by Messinian slope-to-basin and fore-deep deposits, to the south.

We first create a set of geological sections crossing the area of the Amatrice earthquake (CS\#1, CS\#2, CS\#3, and SS\#4 in Fig. 2). For the structural reconstruction of the hanging wall of the Sibillini Thrust we use published geological maps (Pierantoni et al., 2013). For the Laga Basin area we use both geological maps and a structural map of the buried structures (e.g. Bigi et al., 2011; Bigi et al., 2013) based on extensive hydrocarbon exploration carried out in the 1980s and 1990s. Seismic reflection data and well logs are freely accessible (ViDEPI Project, http:/ / unmig.sviluppoeconomico.gov.it/videpi/) and over time led to a number of studies on the buried structures of this area (e.g. Calamita et al., 1994; Scisciani, 2009; Bigi et al., 2011; Bigi et al., 2013).

We then project the relocated aftershocks (updated as of 15 September 2016; Michele et al. 2016) along the geological sections using a symmetric buffer width of $2.5 \mathrm{~km}$ :

- $\quad$ CS\#1 (Figs. 2a-b) shows aftershocks aligned along an hypothetical structure dipping $35^{\circ}-40^{\circ}$ to the WSW. The connection between the aftershock patterns with the low-angle $\left(10^{\circ}\right.$ $20^{\circ}$ ) portion of the Sibillini thrust detectable at surface (e.g. Koopman, 1983; Lavecchia, 1985) seems to depict a ramp-flat structure. Hence, this framework may suggest that this alignment of aftershocks can be interpreted as the negative inversion of the ramp of the Sibillini thrust. This solution competes with an interpretation based on the reactivation of a younger extensional fault. The rectilinear alignment together with the relative low-angle attitude of the aftershock pattern $\left(35^{\circ}-40^{\circ}\right)$ are in favor of the first solution, although a younger extensional system cannot be excluded a priori from this cross-section. The aftershock pattern also suggests the activation of a NE-dipping fault, located in the hanging wall of the Sibillini Thrust according to our framework, which cannot be correlated with any known geological structure, either at the surface or at depth. Either fault are compatible with the focal mechanism of the strongest aftershock ( $\mathrm{M}_{\mathrm{w}}$ 5.4).

- $\quad$ CS\#2 (Figs. 2c-d) shows two aftershock alignments coherent with those seen in CS\#1 and possibly involving the same structures, i.e. a thrust ramp connected with an emerging lowangle portion of the Sibillini Thrust, and a NNE-dipping, blind antithetic fault. 

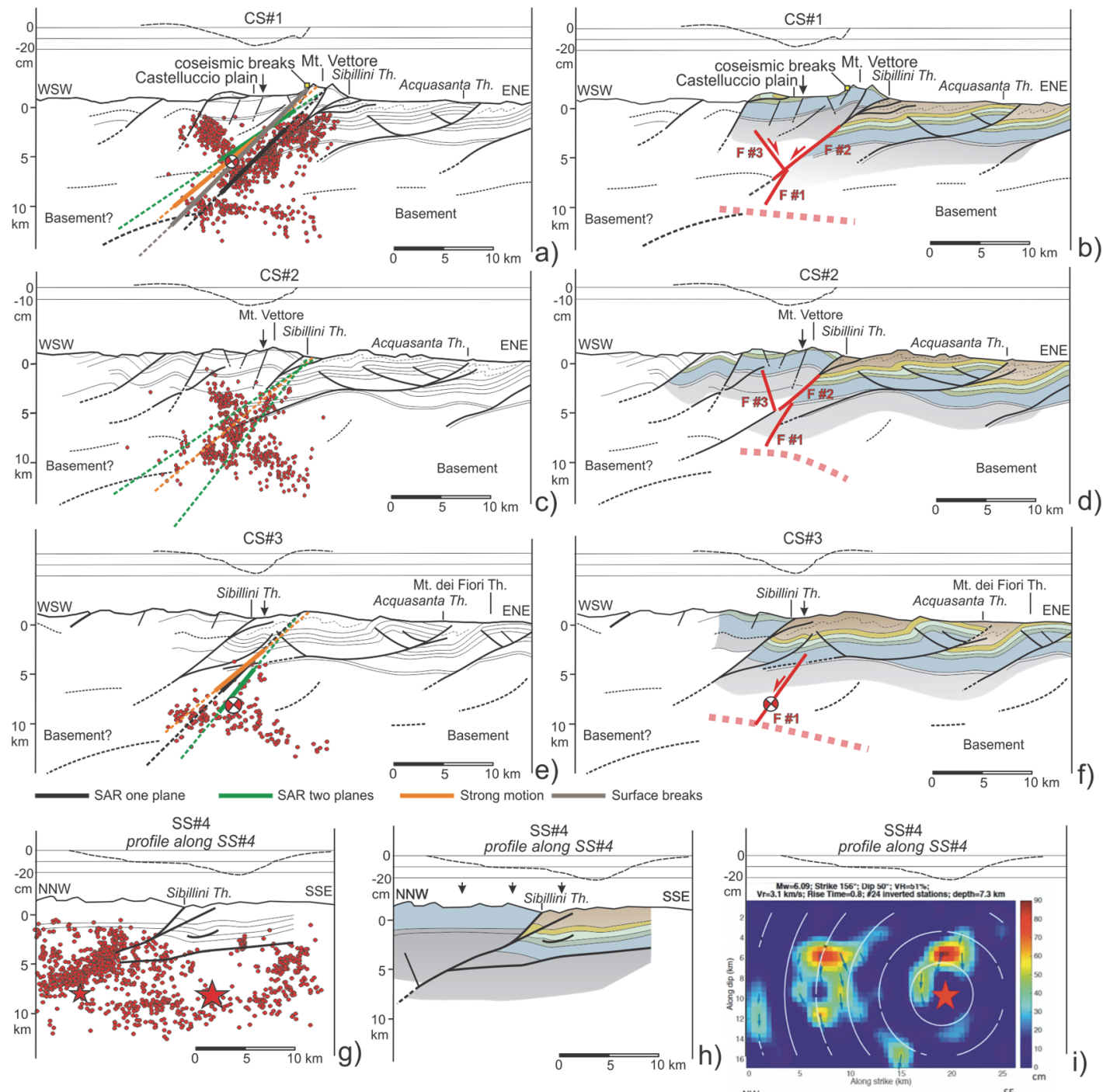

Laga Fm. Cerrogna and Orbulina marls Fms. Umbria-Marche pelagic successions 2 Umbria-Marche pela

NW

Figure 2. (a, c, e, g) Transversal (CSx) and longitudinal (SSx) geological sections across the aftershock pattern of the Amatrice sequence: each panel shows aftershocks falling within a $2.5 \mathrm{~km}$ range from the section plane (updated as of 15 September 2016; data from Michele et al., 2016). The sections also show the trend of model faults derived from InSAR and seismological data. (b, $d, f, h)$ Geological sections showing the main faults that participated in the earthquake sequence (see Discussion section). A profile of InSAR-detected elevation changes (from ALOS-2) is plotted above each section. See Figure 1 for the traces of the sections. i) Model obtained from the inversion of strong motion data, showing the mainshock slip distribution (Tinti et al., 2016). 
The suggested thrust-ramp looks steeper here than in CS\#1 $\left(\sim 40^{\circ}\right.$ instead of $\left.35^{\circ}-40^{\circ}\right)$, a difference that can be explained considering that CS\#2 crosses a lateral ramp of the Sibillini Thrust (e.g. Di Domenica et al., 2014).

- CS\#3 (Figs. 2e-f) shows few aftershocks, likely because the section crosses near the mainshock hypocenter. This observation is consistent with the location of one of the two mainshock slip patches identified using strongmotion data (Tinti et al., 2016).

- $\quad$ SS\#4 (Figs. 2g-h) shows more clearly that the aftershock distribution agrees better with a thrust-ramp connected with the emerging Sibillini Thrust than with a younger extensional fault, further supporting the thrust involvement in the sequence.

In addition to the previously described tectonic features, i.e. the normal faulting source of the mainshock, the portion of the Sibillini Thrust reactivated as a normal fault and the antithetic fault (respectively F\#1, F\#2 and F\#3 in Figure 2), all sections show a cloud of seismicity defining a very low-angle E-dipping plane that extends beneath the source of the mainshock at $\sim 10 \mathrm{~km}$ depth (Fig. 2b-d-f).

\section{DISCUSSION}

Based on the integration of our geological reconstruction with seismological data we suggest that:

1) the mainshock nucleated along a $45^{\circ}$ $50^{\circ}$ blind normal fault located beneath the Laga Basin area (F\#1);

2) the $30^{\circ}-40^{\circ}$ dipping ramp of the Sibillini Thrust has been reactivated in an extensional fashion (negative inversion; $\mathrm{F} \# 2$ );

3) an antithetic normal fault locates in the hanging wall of the Sibillini Thrust (F\#3);
4) a low-angle, E-dipping plane responsible for minor seismicity lies below all the above mentioned faults; its geometry resembles the low-angle normal faults well documented by seismic reflection data to the north of the area illustrated here (i.e. Alto Tiberina Fault; e.g. Collettini and Barchi, 2002).

This interpretation raises two fundamental questions, which we address in the following two subsections:

- what is the nature of the relationship between the mainshock causative fault and the Sibillini Thrust?

- what is the role of previously-mapped active SW-dipping normal faults such as the Vettore fault?

\section{On the role of the Sibillini Thrust}

Two additional elements can contribute to this analysis: 1) the ground-surface displacements derived from InSAR data, and 2) the mainshock slip distribution derived from strong motion data.

InSAR data show a relatively simple pattern formed by the coalescence of two subsidence maxima (Fig. 1b). This pattern is different north and south of the Sibillini Thrust, however: the southern part depicts a narrow, NW-SEtrending oval-shaped bowl, whereas the northern part is a nearly circular bowl with its major axis slightly rotated toward the north. The major axes of the two subsidence maxima exhibit a $10^{\circ}-15^{\circ}$ orientation change. This pattern in itself is suggestive of a change in strike of the seismogenic rupture and of a possible involvement of the Sibillini Thrust.

Models based on the inversion of strong motion data (Tinti et al., 2016) show two maxima (Fig. 2) with predominant dip-slip, respectively located in the region beneath the Laga Basin and 
in the area of the Umbria-Marche carbonates, close to the Castelluccio Plain.
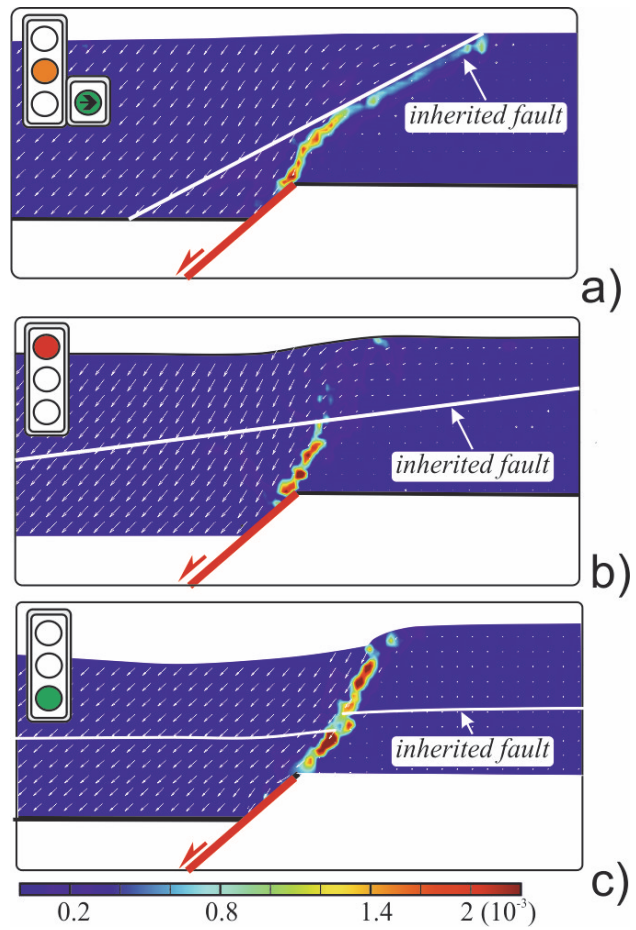

Figure 3. Side view of the analog models from Bonini et al. (2015), modified. Red lines show the initial locations of the extensional faults. White arrows indicate the displacement field measured during the experiments. A white line represents a pre-existing fault. A colored bar below the lowermost panel indicates the strain rates, quantifying the propagation of the extensional fault. A traffic light on top of each panel summarizes the mechanism acting when the extensional fault meets the inherited fault. Notice the crucial role played by the relative dip of the new fault and the older discontinuity.

These two maxima correspond rather well with the regions of maximum surface displacement depicted by InSAR data, indicating that the two models are in good agreement (Fig. 2i).

Adding these two elements to our structural reconstruction combined with the aftershock distribution remarkably improves the picture. The southern maximum subsidence-slip-peak pair corresponds to a region of limited aftershock activity, close to where the mainshock nucleated on a SW-dipping plane. Conversely, the northern maximum subsidence-slip-peak pair corresponds to the region where the aftershock distribution suggests the activation of a more complex fault system: this may include a SWdipping, low-angle fault - likely the Sibillini Thrust - and a NE-dipping fault possibly associated with the Mw 5.4 aftershock, all in addition to the main SW-dipping plane. Hence, the involvement of the normal fault located beneath the Laga basin during the mainshock is also coherent with geodetic and seismological data, whereas what happened more to the north is still unclear.

The faults that slipped in the northern part of the region affected by the Amatrice earthquake include a younger, $40^{\circ}-50^{\circ}$-dipping extensional fault (F\#1) and an older, 30-40'-dipping thrust ramp (F\#2) located above its upper tip (Fig. 2ad). From a mechanical point of view this would imply a simultaneous activity of an extensional fault likely generated during the Quaternary extension - hence relatively youthful - and an inherited structure such as a thrust fault ramp. Over the past few years the relationships between extensional faults and inherited structures have been thoroughly investigated, especially through analog modeling (Bonini et. al., $2015,2016)$. One of the cases investigated by Bonini et al. (2015) analyzed the interaction between a new, extensional fault attempting to grow up-dip and a $30^{\circ}$-dipping thrust ramp located above its upper tip (Fig. 3a), showing that contemporaneous activity of the two structures is mechanically feasible. We maintain that this modeling configuration is reminiscent of the active faults in the central-northern area of the Amatrice sequence. Notice that there is no general rule describing the relationships between new and older faults. For example, a low-angle, 
synthetic fault located above an upward propagating extensional fault tends to slow down or even stop the development of any new faults (Fig. 3b), whereas the development and propagation of the same fault is favored if the inherited fault s horizontal (Fig. 3c).

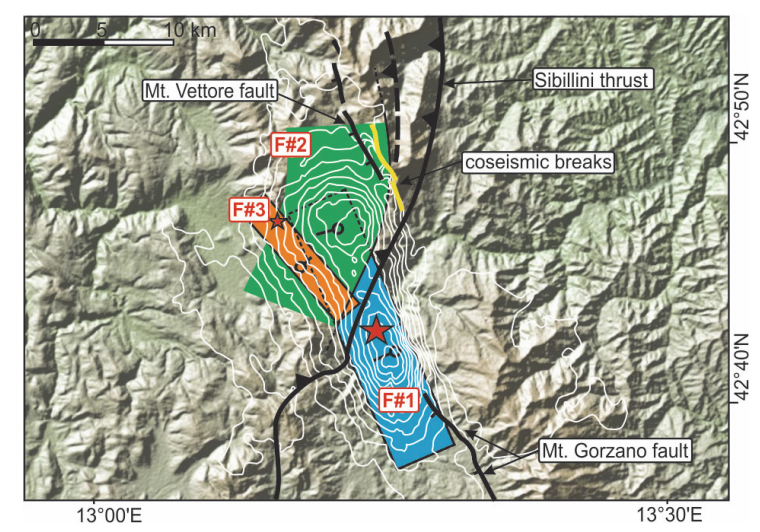

Figure 4. a) Simplified tectonic sketch of the area hit by the Amatrice earthquake sequence. The location of the coseismic breaks seen along the Mt. Vettore Fault is shown in yellow (Emergeo Working Group, 2016). Thin, black and yellow lines are presumed active faults from Galadini and Galli (2003). A thick, black line shows the trace of the Sibillini Thrust. Colored boxes (blue, green and orange) show the simplified surface projection of the three main faults that participated in the earthquake sequence. The pattern of elevation changes detected by ALOS-2 is shown in white.

In summary, the preliminary nature of the data and models available so far does not allow us to confirm whether a portion of the Sibillini Thrust slipped coseismically, with normal sense of movement, during the Amatrice, 24 August 2016 mainshock. However, mechanical models of extensional fault propagation suggest that in the northern portion of the area affected by the Amatrice earthquake there exists a mechanically plausible structural configuration that complies with the active participation of both faults in the earthquake sequence. In other words, the local structural configuration may have encouraged the two faults to work together for accommodating the active NE-SW extension of the Apennines. This configuration may be common to several other cases in the Apennines and elsewhere.

\section{On the role of previously-mapped normal faults}

Two major faults, the Mt. Vettore Fault and the Mt. Gorzano Fault, have been traditionally considered to separately accommodate active extension in the region of the Amatrice earthquake (e.g. Calamita and Pizzi, 1992; Galadini and Galli, 2003; Fig. 4). The ensemble of data collected after the mainshock, however, together with the structural reconstruction illustrated above indicates that neither of them played a primary role in the mainshock of the 24 August, Amatrice earthquake sequence. InSAR observations (see Gruppo di lavoro IREACNR \& INGV, 2016) have shown that the surface breaks identified on the western flank of Mt. Vettore and on its southward prolongation toward Mt. Gorzano could be ascribed to secondary phenomena such as: shaking-induced landsliding, deep-seated gravitational movements, and passive reactivation of secondary faults.The gap between the northern tip of the Mt. Gorzano Fault and the southern tip of the Mt. Vettore Fault is crossed by the Sibillini Thrust, previously recognized as the major boundary between the two fault segments (Pizzi and Galadini, 2009). Our reconstruction suggests that the ramp of the Sibillini thrust system could in itself comprise a seismogenic segment rather than simply a segment boundary. In this view all high-angle faults located in its hanging wall may be considered as secondary faults that may be occasionally remobilized, depending on the amount of extensional reactivation of the thrust ramp. 


\section{CONCLUSIONS}

We reconstructed the causative faults of the 24 August 2016, Amatrice earthquake sequence using geological and seismological data. We found that four main players have been involved. Among them, the SSW-dipping fault located beneath the Laga basin, i.e. very close to the village of Amatrice, is the fault where the mainshock nucleated. The second main player is the deeper portion of the Sibillini Thrust, reactivated in an extensional fashion. The third player is a blind, ENE-dipping fault located in the hanging wall of the Sibillini Thrust. The fourth player is a less defined, low-angle, deeper, east-dipping fault.

Although we discussed the possible role of the Sibillini Thrust during the mainshock, we cannot as yet provide conclusive evidence for its involvement. Nevertheless, aside from its role as an active player rather than simply as a passively reactivated feature, the extensional reactivation of a thrust fault ramp is a rather novel occurrence in the Apennines tectonic scenario, implying a new and more active role for other inherited - i.e. older - tectonic structures.

\section{ACKNOWLEDGEMENTS}

The work was supported by the "Finanziamenti di Ateneo per progetti scientifici - FRA 2015", P.I. Lorenzo Bonini, and the INGV Project "Abruzzo" (code: code RBAP10ZC8K_001; RBAP10ZC8K_003), funded by the Italian Ministry for Education, University and Research (MIUR). The authors thank the guest editors Marco Anzidei and Silvia Pondrelli and an anonymous reviewer for thoughtful reviews of the manuscript that greatly improved the paper.
Bally, A.W, L. Burbi, C. Cooper and R. Ghelardoni (1986). Balanced sections and seismic reflection profiles across the Central Apennines, Memorie della Società Geologica Italiana, 35, 257-310.

Bigi, S., P. Casero and G. Ciotoli (2011). Seismic interpretation of the Laga basin; constraints on the structural setting and kinematics of the Central Apennines, Journal of the Geological Society, 168, 179-190, doi: 10.1144/001676492010-084

Bigi, S., P. Casero, C. Chiarabba and D. Di Bucci, (2013). Contrasting surface active faults and deep seismogenic sources unveiled by the 2009 L'Aquila earthquake sequence (Italy), Terra Nova, 25, 21-29, doi:10.1111/ter.12000.

Bonini, L., D. Di Bucci, G. Toscani, S. Seno and G. Valensise (2014). On the complexity of surface ruptures during normal faulting earthquakes: excerpts from the 6 April 2009 L'Aquila (central Italy) earthquake (M w 6.3), Solid earth, 5(1), 389, doi:10.5194/se-5-12014.

Bonini, L., R. Basili, G. Toscani, P. Burrato, S. Seno and G. Valensise (2015). The role of pre-existing discontinuities in the development of extensional faults: An analog modeling perspective, Journal of Structural Geology, 74, 145-158, doi: 10.1016/j.jsg.2015.03.004.

Bonini, L., R. Basili, G. Toscani, P. Burrato, S. Seno and G. Valensise (2016). The effects of pre-existing discontinuities on the surface expression of normal faults: Insights from wet-clay analog modeling, Tectonophysics, 684, $157-175$ http://dx.doi.org/10.1016/j.tecto.2015.12.015.

Butler, R. W., E. Tavarnelli and M. Grasso (2006). Structural inheritance in moun-

\section{REFERENCES}


tain belts: an Alpine-Apennine perspective, Journal of Structural Geology, 28(11), 18931908, doi: 10.1016/j.jsg.2006.09.006.

Calamita, F., G. Cello, G. Deiana and W. Paltrinieri (1994). Structural styles, chronology rates of deformation, and time-space relationships in the Umbria-Marche thrust system (central Apennines, Italy), Tectonics, 13(4), 873-881, doi: 10.1029/94TC00276.

Calamita, F., W. Paltrinieri, M. Pelorosso, V. Scisciani and E. Tavarnelli (2003). Inherited mesozoic architecture of the Adria continental palaeomargin in the Neogene central Apennines orogenic system, Italy, B. Soc. Geol. It., 122(2), 307-318.

Calamita, F. and A. Pizzi (1992). I "fasci" di faglie recenti ed attive di M. Vettore e di M. Castello-M. Cardoso (Appennino UmbroMarchigiano), Studi Geologici Camerti, volume speciale 1, 81-95.

Cantalamessa, G., E. Centamore, U. Chiocchini, A. Micarelli and M. Potetti (1982). Tectonic-sedimentary evolution of north-western part of the Laga basin during the Upper Miocene-Lower Pliocene (Central-Southern Marche), Mem. Soc. Geol. It., 24, 221-232.

Carafa, M.M.C., and P. Bird (2016). Improving deformation models by discounting transient signals in geodetic data: 2. Geodetic data, stress directions, and long-term strain rates in Italy, Journal of Geophysical Research: Solid Earth, 121(7), 5557-5575, doi: 10.1002/2016JB013038.

CERI Working Group: S. Martino, P. Caporossi, M. Della Seta, C. Esposito, A. Fantini, M. Fiorucci, R. Iannucci, G.M. Marmoni, P. Mazzanti, S. Moretto, S. Rivellino, R.W. Romeo, P. Sarandrea, F. Troiani, C. Varone (2016). EARTHQUAKE CENTRAL APENNINES (ITALY) - UPDATE OF THE
CEDIT INVENTORY, http://www.ceri.uniroma1.it/index.php/2016/08/sisma-centroitalia/.

Collettini C. and M. Barchi (2002). A low angle normal fault in the Umbria region (Central Italy): a mechanical model for the related microseismicity, Tectonophysics, 359, 97115.

Di Domenica, A., L. Bonini, F. Calamita, G. Toscani, C. Galuppo and S. Seno (2014). Analogue modeling of positive inversion tectonics along differently oriented prethrusting normal faults: An application to the Central-Northern Apennines of Italy, Geological Society of America Bulletin, 126, 7-8, 943955, doi:10.1130/B31001.1.

Emergeo Working Group (2016). Coseismic effects of the 2016 Amatrice 1 seismic sequence: first geological results. Annals of Geophysics, The Amatrice seismic sequence: preliminary data and results, Annals of Geophysics, Fast Track 5: The Amatrice seismic sequence: preliminary data and results, DOI: 10.4401/AG-7195

Finocchio D., Barba S., Basili R. (2016). Slip rate depth distribution for active faults in Central Italy using numerical models. Tectonophysics, 687, 232-244, doi: 10.1016/j.tecto.2016.07.031.

Galadini, F., and P. Galli (2003). Paleoseismology of silent faults in the Central Apennines (Italy): the Mt. Vettore and Laga Mts. faults, Annals of Geophysics, 46, 815-836.

Ghisetti, F., and L. Vezzani (1991). Thrust belt development in the central Apennines (Italy): Northward polarity of thrusting and out-of-sequence deformations in the Gran Sasso Chain, Tectonics, 10(5), 904-919, doi: 10.1029/91TC00902.

Gruppo di lavoro IREA-CNR \& INGV (2016). Sequenza sismica di Amatrice: risultati 
iniziali delle analisi interferometriche satellitari, DOI: 10.5281/zenodo.60935.

Koopman, A. (1983). Detachment tectonics in the Central Apennines, Italy. Geol. Ultraiectina, 30, 1-155.

Lavecchia G. (1985). Il sovrascorrimento dei Monti Sibillini: analisi cinematica e strutturale, Boll. Soc. Geol. It., 104, 161-194.

Malinverno, A. and W.B.F. Ryan (1986). Extension in the Tyrrhenian Sea and shortening in the Apennines as result of arc migration driven by sinking of the lithosphere. Tectonics, 5, 227-245.

Michele, M., R. Di Stefano, L. Chiaraluce, M. Cattaneo, P. De Gori, G. Monachesi, D. Latorre, S. Marzorati L. Valoroso, C. Ladina, C. Chiarabba, V. Lauciani and M. Fares (2016). The Amatrice 2016 seismic sequence: a preliminary look to the mainshock and aftershocks distribution, Annals of Geophysics, 59, Fast Track 5: The Amatrice seismic sequence: preliminary data and results.

Pierantoni, P., G. Deiana and S. Galdenzi (2013). Stratigraphic and structural features of the Sibillini Mountains (UmbriaMarche Apennines, Italy), Italian Journal of Geosciences, 132(3), 497-520, doi: 10.3301/IJG.2013.08.
Pizzi, A., and F. Galadini (2009). Pre-existing cross-structures and active fault segmentation in the northern-central Apennines (Italy), Tectonophysics, 476(1), 304-319, doi: 10.1016/j.jsg.2015.03.004.

Scisciani, V. (2009). Styles of positive inversion tectonics in the Central Apennines and in the Adriatic foreland: Implications for the evolution of the Apennine chain (Italy), Journal of Structural Geology, 31(11), 1276-1294, doi: 10.1016/j.jpg.2009.02.004.

Tavarnelli, E. (1996). The effects of preexisting normal faults on thrust ramp development: An example from the northern Apennines, Italy, Geologische Rundschau, 85 (2), 363-371.

Tinti, E., L. Scognamiglio, A. Michelini and M. Cocco (2016). Slip heterogeneity and directivity of the ML 6.0, 2016, Amatrice earthquake estimated with rapid finite-fault inversion, Geophysical Research Letters, DOI: 10.1002/2016GL071263.

Vannoli, P., P. Burrato, U. Fracassi, and G. Valensise (2012). A fresh look at the seismotectonics of the Abruzzi (Central Apennines) following the 6 April 2009 L'Aquila earthquake (M-w 6.3), Ital. J. Geosci., 131, 3, 309-329, doi: 10.3301/ijg.2012.03. 